Federal Reserve Bank of Dallas

Globalization and Monetary Policy Institute

Working Paper No. 307

https://www.dallasfed.org/ /media/documents/institute/wpapers/2017/0307.pdf

\title{
Explaining International Business Cycle Synchronization: Recursive Preferences and the Terms of Trade Channel*
}

\author{
Robert Kollmann \\ Université Libre de Bruxelles and CEPR
}

March 2017

\begin{abstract}
The business cycles of advanced economies are synchronized. Standard macro models fail to explain that fact. This paper presents a simple model of a two-country, two-traded good, complete-financial-markets world in which country-specific productivity shocks generate business cycles that are highly correlated internationally. The model assumes recursive intertemporal preferences (Epstein-Zin-Weil), and a muted response of labor hours to household wealth changes (due to Greenwood-Hercowitz-Huffman period utility and demand-determined employment under rigid wages). Recursive intertemporal preferences magnify the terms of trade response to country-specific shocks. Hence, a productivity (and GDP) increase in a given country triggers a strong improvement of the foreign country's terms of trade, which raises foreign labor demand. With a muted labor wealth effect, foreign labor and GDP rise, i.e. domestic and foreign real activity commove positively.
\end{abstract}

JEL codes: F31, F32, F36, F41, F43

\footnotetext{
* Robert Kollmann, European Centre for Advanced Research in Economics and Statistics (ECARES), Université Libre de Bruxelles, 50 Av. Franklin Roosevelt, 1050 Brussels, Belgium. robert_kollmann@yahoo.com. www.robertkollmann.com. I thank Nelson Mark, Werner Roeger, Gauthier Vermandel, Roland Winkler and workshop participants at the Fed Board of Governors, Dallas Fed and at the IMAC3-Rennes conference for useful discussions. The research leading to these results has received funding from the European Community's Seventh Framework Programme (FP7/2007-2013) under grant agreement no. 612796, Project MACFINROBODS ('Integrated Macro-Financial Modelling for Robust Policy Design'). The views in this paper are those of the author and do not necessarily reflect the views of the Federal Reserve Bank of Dallas or the Federal Reserve System.
} 


\section{Introduction}

Cyclical fluctuations of GDP, labor and investment are highly positively correlated across advanced economies. Standard macroeconomic models fail to explain that key fact--in those models, shocks originating in one country have a weak effect on foreign real activity, and predicted cross-country business cycle correlations are markedly smaller than empirical correlations. Explaining international business cycle synchronization is thus one of the main challenges for macroeconomics (e.g., Backus et al. $(1992,1994)$ ). The present paper provides a possible resolution of the 'international correlation puzzle'. It develops a simple dynamic general equilibrium model in which country-specific productivity shocks induce internationally synchronized business cycles.

A two-country world with two traded goods is considered. The specification of production and market structures follows standard International Real Business Cycle (RBC) models; see, e.g., Backus et al. (1994). ${ }^{1}$ Each country is inhabited by a representative household who produces one traded good using domestic capital and labor. Households use domestic and imported traded goods for consumption and physical investment, but there is a spending bias towards the domestic traded good. Financial markets are complete, so that consumption risk is efficiently shared across countries. Economic fluctuations are driven by persistent exogenous productivity shocks.

The model differs from standard open economy macro models by assuming recursive intertemporal preferences (Epstein and Zin (1989), Weil (1989, 1990)), whereas conventional international macro models assume time-separable preferences. Recursive preferences magnify the terms of trade response to country-specific shocks. Hence, a productivity (and GDP) increase in a given country can trigger a strong improvement of the foreign country's terms of trade, which raises foreign labor demand. With a muted labor wealth effect, foreign labor and GDP rise, i.e. domestic and foreign real activity comove positively. I show that the structure with recursive preferences and a muted labor wealth effect can generate sizable cross-country business cycle correlations. The model can reproduce the empirical fact that cross-country correlations of GDP, total hours worked and investment growth rates are markedly higher than the cross-country

\footnotetext{
${ }^{1}$ Other related International RBC models include Dellas (1986), Cantor and Mark (1988), Crucini (1989), Devereux et al. (1992), Kollmann (1991,1996), and Heathcote and Perri (2002).
} 
correlation of total factor productivity growth. The model also generates higher, more realistic, real exchange rate volatility than conventional macro models.

To highlight the role of the labor wealth effect for cross-country shock transmission, I consider a period utility function à la Greenwood, Hercowitz and Huffman (1988) [GHH] that entails a zero wealth effect on desired labor supply. By contrast, the more widely used King, Plosser and Rebelo (1989) [KPR] period utility function implies a negative response of desired labor supply to a wealth increase. I also study a setting in which the wage rate expressed in aggregate consumption units (the 'consumption wage rate') is rigid in the short-run, and hours worked are determined by firms' labor demand, while workers can be off their desired labor supply schedule; this also mutes the (negative) labor wealth effect, and it induces especially powerful crosscountry shock transmission, in conjunction with recursive preferences.

Consider the effect of a persistent exogenous productivity increase in one of the two countries, named 'Home'. That positive aggregate supply shock induces a persistent rise in Home GDP, hours worked, consumption and investment; it lowers the relative price of the Home output good (compared to the Foreign output good), i.e. the Home terms of trade deteriorate. Thus, the other country's ('Foreign') terms of trade improve. This raises the value marginal product of labor in the Foreign country, relative to the price of Foreign aggregate consumption; hence, Foreign firms' labor demand rises (at any consumption wage rate). Under wage flexibility, the equilibrium Foreign consumption wage rate increases, thus. With standard period utility, this induces opposing substitution and wealth effects on Foreign labor supply, with the former increasing, and the latter decreasing the Foreign household's desired hours worked. The present paper discusses models in which the counteracting labor wealth effect is muted. I show that a set-up with a weak labor wealth effect can generate a sizable rise in Foreign hours worked and GDP (in response to a Home productivity increase), if the Foreign terms of trade improve strongly (as this powerfully boosts Foreign labor demand).

With complete financial markets, the (gross) rate of appreciation of the Home real exchange rate is equated, in equilibrium, to the ratio of the Home intertemporal marginal rate of substitution in consumption (IMRS) to the Foreign IMRS. Under time separable intertemporal preferences, the real exchange rate (and terms of trade) response to a 
supply shock is weak, as the shock has a muted effect on the relative Home/Foreign IMRS (e.g., Backus et al. (1994)), and cross-country shock transmission is likewise weak. Recursive intertemporal preferences magnify the real exchange rate (and terms of trade) response to a country-specific productivity shock; with recursive preferences, the shock can thus induce strong positive cross-country comovement of real activity, if the labor wealth effect is muted.

Under recursive intertemporal preferences, the coefficient of risk aversion (CRA) may differ from the inverse of the intertemporal elasticity of substitution (IES). (By contrast, $\mathrm{CRA}=1 / \mathrm{IES}$ holds under standard time-separable preferences.) Crucially, when CRA $\neq 1 /$ IES, then a household's IMRS depends on her (future) lifetime utility. Under the common assumption that CRA>1/IES (e.g. Swanson (2014)), the IMRS is decreasing in (future) life-time utility. ${ }^{2}$ A persistent rise in Home productivity increases Home life-time utility, which lowers the Home IMRS, when CRA $>1 /$ IES. $^{3}$ This implies that, in response to a Home productivity increase, the Home real exchange rate depreciates more strongly under recursive preferences than under time-separable preferences. Efficient risk sharing under recursive preferences with high risk aversion (CRA $>1 /$ IES) implies that the Home household (whose relative IMRS has dropped) makes a sizable wealth transfer to the Foreign household (the Home net foreign asset position falls, on impact). That risk sharing transfer (triggered by the Home productivity increase) boosts demand for the Foreign traded good (and lowers demand for the Home traded good), which amplifies the deterioration of the Home terms of trade and the depreciation of the Home real exchange rate; the wealth transfer thereby aligns the relative Home/Foreign IMRS and the real exchange rate change.

Importantly, recursive preferences (generating a strong terms of trade response) and a muted labor wealth effect (due to GHH period utility and/or consumption wage rigidity) are jointly needed for cross-country business synchronization. In a flex-wage setting with KPR period utility (negative labor wealth effect), the assumption of recursive preferences lowers the predicted cross-country correlation of labor hours and output (compared to time-separable preferences), i.e. the 'international correlation puzzle'

\footnotetext{
${ }^{2}$ CRA $>1 /$ IES implies a preference for the early resolution of uncertainty over future consumption (Weil, 1990).

${ }^{3}$ In response to the Home productivity increase, Foreign life-time utility rises too, but less than Home lifetime utility (due i.a. to the local spending bias); thus, the relative Home/Foreign IMRS falls.
} 
worsens. Intuitively, the wealth transfer from Home to Foreign that is triggered, under recursive preferences, by a Home productivity increase, dampens the expansion of Foreign hours worked and output, when the labor wealth effect is negative.

The asset pricing literature has for long used models with recursive preferences, as the separation between the CRA and IES parameters helps to capture the joint behavior of financial returns and consumption (e.g., Rudebusch and Swanson (2012)). By contrast, the international macro literature has only recently begun to study models with recursive preferences. Most open economy models with recursive preferences assume endowment economies; see, e.g., Kollmann (2009, 2015, 2016), Colacito and Croce (2011, 2013), Küçük (2011), Gourio et al. (2013), Caporale et al. (2014), Dou and Verdelhan (2015), Lewis and Liu (2015), Lustig and Verdelhan (2015), and Sauzet (2015). Endowment models cannot endogenously explain the cross-country correlation of real activity, the focus of the present paper. Open economy models with recursive preferences and endogenous production have been analyzed by Kollmann (2010), Benigno et al. (2012), Colacito et al. (2014), Mumtaz and Theodoridis (2015), Backus et al. (2016) and Tretvoll (2016), but the focus of these papers is different. ${ }^{4}$ Among other differences, those models do not feature the positive international transmission channel induced by a muted labor wealth effect (due especially to wage rigidity), that the present paper identifies and highlights; those previous models fail to generate simultaneously high cross-country correlations of output, of total hours worked and of investment.

The paper here is also related to several studies that have explored open economy models with GHH period utility, but without considering recursive intertemporal preferences or analyzing the role of the muted labor wealth effect for the cross-country correlation of real activity; e.g., Devereux et al. (1992), Correia and Rebelo (1995), Jaimovich and Rebelo (2008) and Raffo (2010).

Section 2 describes the baseline two-country model with production and recursive preferences. Section 3 discusses stylized facts about international business cycles. Section 4 presents simulation results and Section 5 concludes.

\footnotetext{
${ }^{4}$ Kollmann (2010) and Tretvoll (2016) analyze the determinants of real exchange rate variability. Benigno et al. (2012), Mumtaz and Theodoridis (2015) and Backus et al. (2016) study the effect of volatility shocks. Colacito et al. (2014) explore differential effects of permanent and transitory productivity shocks on international capital flows.
} 


\section{A two-country model}

\subsection{Preferences, technologies, shock process, risk sharing}

A world with two symmetric countries, Home $(H)$ and Foreign $(F)$, is assumed. Each country is inhabited by a representative infinitely-lived household.

At date $t$, perfectly competitive firms in country $i$ produce $Y_{i, t}$ units of a perishable tradable intermediate good $i$, using the technology

$$
Y_{i, t}=\left(L_{i, t} \theta_{i, t}\right)^{\omega}\left(K_{i, t}\right)^{1-\omega}, 0<\omega<1,
$$

where $L_{i, t}$ and $K_{i, t}$ are hours worked and capital, respectively. The country $i$ capital stock is owned by the local household and rented to the domestic firms. Labor and capital are immobile internationally. $\theta_{i, t}>0$ is exogenous stochastic labor augmenting productivity in country $i$. Productivity is non-stationary (see below).

The country $i$ household combines local and imported intermediates into a nontradable final good, $Z_{i, t}$ :

$$
Z_{i, t} \equiv\left(y_{i, t}^{i} /(1-\alpha)\right)^{1-\alpha}\left(y_{i, t}^{j} / \alpha\right)^{\alpha}, j \neq i,
$$

where $y_{i, t}^{j}$ is the amount of intermediate good $j$ used by country $i$. There is a bias towards using the local input: $0<\alpha<0.5$. The final good is used for consumption, $C_{i, t}$, and gross investment, $I_{i, t}: Z_{i, t}=C_{i, t}+I_{i, t}$. The law of motion of the capital stock is $K_{i, t+1}=(1-\delta) K_{i, t}+I_{i, t}$, where $0<\delta<1$ is the capital depreciation rate.

At date $t$, the price of country $i$ 's final good $\left(P_{i, t}\right)$ equals its marginal cost: $P_{i, t}=\left(p_{i, t}\right)^{1-\alpha}\left(p_{j, t}\right)^{\alpha}, j \neq i$, where $p_{j, t}$ is the price of intermediate good $j$. Input demands are: $y_{i, t}^{i}=(1-\alpha) P_{i, t} Z_{i, t} / p_{i, t}, \quad y_{i, t}^{j}=\alpha P_{i, t} Z_{i, t} / p_{j, t}$ for $j \neq i$. Market clearing for tradable goods requires $y_{H, t}^{i}+y_{F, t}^{i}=Y_{i, t}$ for $i=H, F$. Country $i$ 's terms of trade and real exchange rate are defined as

$$
q_{i, t} \equiv p_{i, t} / p_{j, t} \text { and } R E R_{i, t} \equiv P_{i, t} / P_{j, t} \text {, with } i \neq j,
$$

respectively. Thus, increases in $q_{i, t}$ and $R E R_{i, t}$ represent an improvement in the country $i$ terms of trade, and an appreciation of its real exchange rate, respectively. Note that 
$\operatorname{RER}_{i, t}=\left(q_{i, t}\right)^{1-2 \alpha}$; due to home bias $(1-2 \alpha>0)$, an improvement of a country's terms of trade is accompanied by an appreciation of its real exchange rate.

The country $i$ household has a concave period utility function that is increasing in consumption and decreasing in hours worked:

$$
u_{i, t}\left(C_{i, t}, L_{i, t}\right)=\frac{1}{1-\sigma}\left[\psi_{i, t}\left(C_{i, t}, L_{i, t}\right)\right]^{1-\sigma}, \quad \sigma>0, \quad \sigma \neq 0,
$$

where $\psi_{i, t}\left(C_{i, t}, L_{i, t}\right)>0$ is an affine function of $C_{i, t}$ (see below).

Intertemporal household preferences are described by a recursive life-time utility function inspired by Epstein and Zin (1989), and Weil (1989, 1990):

$$
U_{i, t}=\left\{\left(1-\beta_{i, t}\right) \cdot\left[\psi_{i, t}\left(C_{i, t} L_{i, t}\right)\right]^{1-\sigma}+\beta_{i, t} \cdot\left[E_{t} U_{i, t+1}^{1-\gamma}\right]^{(1-\sigma) /(1-\gamma)}\right\}^{1 /(1-\sigma)},
$$

where $U_{i, t}>0$ is country $i$ life-time utility at date $t$. (Epstein, Zin and Weil assume that utility only depends on consumption. The specification of recursive preferences used here, that also depends on labor, follows Rudebusch and Swanson (2012).) $0<\beta_{i, t}<1$ is $i$ 's subjective discount factor between periods $t$ and $t+1,1 / \sigma$ is the intertemporal elasticity of substitution (IES). $\gamma$ indexes the household's aversion against uncertainty in future life-time utility. Standard time-separable preferences obtain when $\gamma=\sigma$, i.e. when $\gamma=1 /$ IES. Epstein, Zin and Weil assume that the subjective discount factor is constant. To ensure that the model has a unique deterministic steady state, and an equilibrium in which the consumption/GDP ratio is stationary, I posit that the subjective discount factor of household $i$ is a decreasing function of its period utility (normalized by productivity): $\beta_{i, t}=\bar{\beta}-b \cdot \ln \left(\widetilde{u_{i, t}} / \tilde{u}\right)$ for $\sigma<1$ and $\beta_{i, t}=\bar{\beta}+b \cdot \ln \left(-\widetilde{u_{i, t}} / \widetilde{u_{i}}\right)$ for $\sigma>1$, with $\mathrm{b}>0$. Here $\widetilde{u_{i, t}} \equiv u_{i, t} / X_{t}^{1-\sigma}$ and $\widetilde{u_{i}}$ is the steady state value of $\widetilde{u_{i, t}} ; X_{i, t}>0$ is a weighted geometric average of past productivity:

$$
X_{i, t}=\left(X_{i, t-1}\right)^{1-\eta}\left(\theta_{i, t-1}\right)^{\eta}, \text { with } 0 \leq \eta<1 .
$$

Country $i$ 's intertemporal marginal rate of substitution (IMRS) between aggregate consumption at dates $t$ and $t+1$ is:

$$
\rho_{i, t+1} \equiv \beta_{i, t} \frac{\Psi_{i, t+1}}{\Psi_{i, t}} \frac{\partial u_{i, t+1} / \partial C_{i, t+1}}{\partial u_{i, t} / \partial C_{i, t}}\left(\frac{U_{i, t+1}}{\left(E_{t} U_{i, t+1}^{1-\gamma}\right)^{1 /(1-\gamma)}}\right)^{\sigma-\gamma},
$$


with $\Psi_{i, t} \equiv 1-\beta_{i, t}-\left(b / \beta_{i, t}\right) \cdot\left[\left(U_{i, t} / \psi_{i, t}\right)^{1-\sigma}-1\right] .{ }^{5}$ Note that when $\gamma=\sigma$ and $b=0$ is assumed, then $\rho_{i, t+1}=\bar{\beta} \cdot\left(\partial u_{i, t+1} / \partial C_{i, t+1}\right) /\left(\partial u_{i, t} / \partial C_{i, t}\right)$, i.e. the IMRS only depends on consumption and hours at $t$ and $t+1$. When $\gamma \neq \sigma$, then the IMRS depends also on life-time utility $U_{i, t+1}$. When $\gamma>\sigma$, then an unexpected rise in $U_{i, t+1}$ induces a fall in the IMRS.

The model assumes complete international financial markets. In equilibrium, the Home/Foreign IMRS ratio is thus equated to the growth factor of the Home real exchange rate (Kollmann (1991, 1995), Backus and Smith (1993)):

$$
\rho_{H, t+1} / \rho_{F, t+1}=R E R_{H, t+1} / R E R_{H, t} .
$$

The market value of country $i$ 's net foreign assets at the end of period $t$ (expressed in units of aggregate consumption), $N F A_{i, t+1}$, equals the present value of $i$ 's future net imports: $N F A_{i, t+1}=E_{t} \sum_{k=1}^{\infty} \rho_{i, t, t+k} \cdot\left(P_{i, t} / P_{i, t+k}\right) \cdot\left(-N X_{i, t+k}\right)$, where $N X_{i, \tau} \equiv p_{i, \tau} Y_{i, \tau}-P_{i, \tau}\left(C_{i, \tau}+I_{i, \tau}\right)$ are net exports at date $\tau$ and $\rho_{i, t, t+k} \equiv \prod_{v=1}^{v=k} \rho_{i, t+v}$.

Optimal country $i$ capital investment decisions are described by the Euler equation

$$
1=E_{t} \rho_{i, t+1}\left\{\left(p_{i, t+1} / P_{i, t+1}\right) \cdot M P K_{i, t+1}+1-\delta\right\},
$$

where $M P K_{i, t+1} \equiv(1-\omega) Y_{i, t+1} / K_{i, t+1}$ is the date $t+1$ physical marginal product of capital. Let $w_{i, t}$ denote the wage rate, in aggregate consumption units (the 'consumption wage rate'). Intermediate good producing firms equate the marginal product of labor, in aggregate consumption units, to the consumption wage rate:

$$
\left(p_{i, t} / P_{i, t}\right) \cdot M P L_{i, t}=w_{i, t},
$$

where $M P L_{i, t+1} \equiv \omega Y_{i, t} / L_{i, t}$ is the physical marginal product of labor. The relative price between country $i$ 's output and aggregate consumption is an increasing function of the country's terms of trade (and hence also of its real exchange rate): $p_{i, t} / P_{i, t}=\left(q_{i, t}\right)^{\alpha}$. Thus, an (expected) improvement in the future terms of trade raises the future marginal product of capital, in aggregate consumption units, $\left(p_{i, t+1} / P_{i, t+1}\right) \cdot M P K_{i, t+1}$, which increases the demand

\footnotetext{
${ }^{5}$ In the numerical simulations, $b$ is set at a very small value, which implies that the term $\beta_{i, t} \Psi_{i, t+1} / \Psi_{i, t}$ in (4) makes a negligible contribution to high-frequency fluctuations of $\rho_{i, t+1}$.
} 
for capital (investment). Similarly, a terms of trade improvement raises the marginal product of labor, expressed in consumption units, $\left(p_{i, t} / P_{i, t}\right) \cdot M P L_{i, t}$. This increases labor demand in country $i$, at any given consumption wage rate $w_{i, t}$.

As shown below, a positive shock to Home productivity improves the Foreign terms of trade. This boosts Foreign labor demand. Thus, the Foreign consumption wage rate increases, under flexibility of the consumption wage rate. With standard period utility functions, this induces opposing substitution and wealth effects on Foreign labor supply, with the former increasing and the latter decreasing the Foreign household's desired hours worked.

To highlight the role of the labor wealth effect for international shock transmission, I compare model variants with the King, Plosser and Rebelo (1989) [KPR] period utility function that is widely used in the international macro literature (e.g. Backus et al. (1994)), to model variants with period utility à la Greenwood, Hercowitz and Huffman (1988) [GHH]. Under KPR period utility, a wealth increase triggers a fall in desired labor supply. By contrast, the wealth effect on labor supply is zero under GHH period utility.

KPR period utility obtains when $\psi_{i, t}\left(C_{i, t}, L_{i, t}\right)=C_{i, t} \zeta\left(L_{i, t}\right)$, with $\zeta>0, \quad \zeta^{\prime}<0$ (see (2)). ${ }^{6}$ The model variants with GHH period utility assume $\psi_{i, t}\left(C_{i, t}, L_{i, t}\right)=C_{i, t}+X_{i, t} v\left(L_{i, t}\right)$, with $v>0$ and $v^{\prime}, v^{\prime \prime}<0 ; X_{i, t}>0$ is the weighted geometric average of past productivity defined in (3). ${ }^{7}$ The simulations below use these functional forms of labor disutility:

$$
\zeta\left(L_{i, t}\right)=1+v\left(L_{i, t}\right), \text { with } v\left(L_{i, t}\right)=-\frac{1}{1+1 / \eta} \cdot\left\{\left(L_{i, t}\right)^{1+1 / \eta}-L^{1+1 / \eta}\right\},
$$

where $L$ denotes steady state hours.

The household determines her desired labor supply by equating the marginal rate of substitution between consumption and leisure to the consumption wage: $m r s_{i, t}=w_{i, t}$, where $m r s_{i, t} \equiv-\left(\partial \psi_{i, t} / \partial L_{i, t}\right) /\left(\partial \psi_{i, t} / \partial C_{i, t}\right)$. Under KPR period utility, $m r s_{i, t}=-C_{i, t} \zeta^{\prime}\left(L_{i, t}\right) / \zeta\left(L_{i, t}\right)$

\footnotetext{
${ }^{6}$ Concavity of the KPR period utility function requires $\zeta^{\prime \prime}<(2-1 / \sigma)\left(\zeta^{\prime}\right)^{2} / \zeta$.

${ }^{7}$ Under GHH utility, the disutility of labor is scaled by $X_{\mathrm{i}, \mathrm{t}}$ to permit balanced growth, and to ensure that equilibrium hours worked are stationary; the $X_{\mathrm{i}, \mathrm{t}}$ term can be rationalized by assuming that there is household home production (e.g., Rudebusch and Swanson (2012)). KPR period utility is consistent with balanced growth and stationary hours when the disutility of work is not scaled by productivity.
} 
holds. Thus, under KPR utility, a rise in consumption increases the marginal rate of substitution, which raises the household's asking wage. A shock that raises the wage $w_{i, t}$ and consumption, thus has an ambiguous effect on desired labor supply, under KPR period utility. ${ }^{8}$ Under GHH period utility, by contrast, $m r s_{i, t}=-X_{i, t} v^{\prime}\left(L_{i, t}\right)$, i.e. the marginal rate of substitution does not depend on consumption (zero labor wealth effect); given the exogenous quantity $X_{i, t}$, an increase in the consumption wage rate raises desired labor supply unambiguously.

I compare model variants with a flexible consumption wage rate, in which labor demand equals the household's desired labor supply $\left(p_{i, t} M P L_{i, t} / P_{i, t}=w_{i, t}=m r s_{i, t}\right)$, to model variants with wage rigidity, in which the real consumption wage rate is assumed to be set one period in advance, at the expected future marginal rate of substitution between consumption and leisure: $w_{i, t}=E_{t-1} m r s_{i, t}$. Under a predetermined consumption wage rate, labor hours are determined by firms' labor demand (6); thus, households can (temporarily) be off their desired labor supply schedule $\left(w_{i, t} \neq m r s_{i, t}\right)$, which mutes the (negative) wealth effect on hours worked. ${ }^{9}$

Empirical fluctuations of productivity, and of relative (domestic/foreign) productivity, are highly persistent. The model assumes that log productivity has a unit root, and that log productivity is co-integrated across countries:

$$
\ln \left(\theta_{i, t+1}\right)-\ln \left(\theta_{i, t}\right)=-\kappa \cdot\left[\ln \left(\theta_{i, t}\right)-\ln \left(\theta_{j, t}\right)\right]+\varepsilon_{i, t+1}^{\theta} \text {, with } 0<\kappa<\frac{1}{2} \text {, for } i=H, F \text { and } j \neq i,
$$

where $\varepsilon_{i, t+1}^{\theta}$ is a Gaussian white noise.

\subsection{Numerical solution method}

As productivity is assumed non-stationary, but cointegrated across countries, I reformulate the model by normalizing country $i$ GDP, consumption, investment, net exports and utility by $i$ 's (labor augmenting) productivity. The model has a stationary equilibrium, in terms of the normalized variables. I solve the reformulated model with the

\footnotetext{
${ }^{8}$ Holding consumption constant, a rise in the wage rate $w$ induces an increase in desired labor supply, as $-\zeta^{\prime} / \zeta$ is increasing in hours worked; for a given wage rate $w$, a rise in consumption lowers desired hours worked (negative wealth effect), under KPR period utility.

${ }^{9}$ Rigid-wage models usually assume that hours are demand-determined (e.g., Blanchard and Gali (2007), Kollmann et al. (2016)).
} 
Dynare toolbox (Adjemian et al. (2014)) using a third-order approximation around the symmetric deterministic steady state.

\subsection{Calibration}

\subsubsection{Preference and technology parameters}

One period represents one quarter. The steady state subjective discount factor and the slope parameter of the endogenous discount factor are set at $\bar{\beta}=0.99$ and $b=0.001$, respectively. ${ }^{10}$ The intertemporal elasticity of substitution (IES) $1 / \sigma$ is set at 1.5 , in line with standard values used in the macro literature. Following the macro-finance literature (e.g. Swanson (2014)), I consider high risk aversion coefficients: $\gamma=10$ and $\gamma=50$ (recursive preferences); however, I also discuss a case with $\gamma=1 / \mathrm{IES}=0.66$ (time-separable preferences). The Frisch labor supply elasticity is set at 2, a standard value used in macro models; that elasticity generates hours volatility broadly in line with the data. ${ }^{11}$

The model will be evaluated by comparing model-predicted business cycle statistics to empirical statistics of 1973-2013 quarterly data for the US and for an aggregate of 13 other OECD economies (hereafter named 'rest of the world', ROW) for which quarterly aggregate hours worked series were constructed by Ohanian and Raffo $(2012,2014){ }^{12}$ Long historical quarterly times on total hours worked are only available for these 13 countries and for the US (the US hours data used here is the BLS series 'hours of wage and salary workers on nonfarm payrolls'). The choice of 13 ROW countries is thus dictated by the availability of quarterly hours data (that are needed for estimating quarterly productivity series, the driving force of economic fluctuations in the model).

\footnotetext{
${ }^{10}$ The small value of $b$ implies that short term model dynamics are similar to those generated by a (nonstationary) model variant with a constant subjective discount factor $(b=0)$.

${ }^{11}$ Under KPR period utility, the Frisch labor supply elasticity (LSE), evaluated at the steady state, is $\mathrm{LSE}=1 /\left(1 / \eta+\omega / s_{C}\right)$, where $\eta$ is the curvature of labor disutility (see (7)) and $s_{C}$ is the steady state consumption/GDP ratio. $s_{C}$ depends solely on $\omega, \delta$ and $\bar{\beta}$. Under GHH utility, LSE $=\eta$.

${ }^{12}$ The 13 ROW countries are: Australia, Austria, Canada, Finland, France, Germany, Ireland, Italy, Japan, Korea, Norway, Sweden, UK. The Ohanian-Raffo quarterly labor hours data (available until 2013) are estimated from time series on employment and hours worked per employee (ILO, OECD).
} 
The labor share is calibrated at $\omega=0.65$, consistent with US and ROW data. ${ }^{13}$ The depreciation rate of capital is set at $\delta=0.025$, as in standard quarterly macro models. In 1973-2013, the mean US trade share (0.5 - (exports+imports)/GDP) was 10\%. Hence, the import share parameter in the model is set at $\alpha=0.10$ (see (1)).

\subsubsection{Exogenous process}

I calibrate the parameters of the productivity process (8) to quarterly US and ROW labor augmenting productivity series (1973-2013). As an empirical measure of ROW aggregate productivity, I use a GDP-weighted index of productivity in the 13 individual ROW countries. ${ }^{14}$ The historical standard deviations of first differenced quarterly US and (aggregate) ROW log productivity are $0.88 \%$ and $0.68 \%$, respectively, i.e. the average standard deviation (across the two regions) is $0.78 \%$. The empirical correlation between US and ROW productivity growth is 0.13 . In the calibrated model, I thus set the standard deviation of $\Delta \ln \left(\theta_{i, t}\right)$ at $0.78 \%$ (for $\left.i=\mathrm{H}, \mathrm{F}\right)$; the correlation between $\Delta \ln \left(\theta_{H, t}\right)$ and $\Delta \ln \left(\theta_{F, t}\right)$ is set at 0.13. An Augmented Dickey-Fuller test fails to reject the hypothesis that relative US/ROW productivity has a unit root. To ensure stationarity of the normalized model, the productivity error correction parameter (see (8)) is set at a small positive value, $\kappa=0.001$. The partial adjustment parameter of the preference shifter $X_{i, t}$ (see (3)) is set at $\eta=0.001$, which ensures that a productivity shock has a negligible short-run effect on preferences.

\section{Stylized facts about international business cycles}

Table 1 reports historical business cycle statistics (1973-2013) for quarterly US and ROW GDP, consumption, gross investment, total hours worked and net exports (NX), and for the US real effective exchange rate (CPI-based). The empirical consumption

\footnotetext{
${ }^{13}$ In the model, the share of GDP going to labor equals $\omega$; the sample average of the labor share (compensation of employees/(GDP net of indirect taxes)) is 0.64 (0.66) in the US (ROW).

${ }^{14} \mathrm{I}$ construct empirical $\log$ productivity (labor augmenting) for country $i$ as $\ln \left(\theta_{i, t}\right)=$ $\left(\ln \left(G D P_{i, t}\right)-\omega_{i} \ln \left(L_{i, t}\right)-\left(1-\omega_{i}\right) \ln \left(K_{i, t}\right)\right) / \omega_{i}$, where $\omega_{i}$ is the sample average of $i$ 's wage share. The labor input measure is total hours worked; quarterly capital series are cubic spline interpolates of annual capital stocks from the Penn World Table. A Törnqvist index is used to construct aggregate ROW productivity $\left(\theta_{R O W, t}\right)$ : $\Delta \ln \theta_{R O W, t}=\sum_{j=1}^{13} s_{j, t} \Delta \ln \theta_{j, t}$ where $s_{j, t}$ is the weight of country $j$ at date $t$, with $\sum_{j} s_{j, t}=1$. The weights are countries' smoothed nominal GDP shares in aggregate ROW nominal US\$ GDP, at current exchange rates (to reduce the effect of nominal exchange rate volatility, exponential time trends are fitted to raw GDP shares, and fitted trend shares are used as weights).
} 
measure is the sum of private and government consumption. Net exports are normalized by domestic GDP. ${ }^{15}$ The statistics shown in Table 1 pertain to first differenced quarterly data. GDP, consumption, investment, labor hours and the real exchange rate are logged before first differencing.

The historical standard deviation of GDP growth is $0.81 \%$ in the US, and $0.59 \%$ in the ROW. The Table reports 'relative standard deviations' of other variables, i.e. standard deviations divided by the standard deviation of GDP. Relative standard deviations are broadly similar across the US and the ROW. Consumption, net exports and hours worked are less volatile than GDP, while investment and the real exchange rate are 3-4 times more volatile than GDP. Consumption, investment and hours worked are procyclical (positively correlated with domestic GDP). US net exports are countercyclical; the US real exchange rate is weakly countercyclical.

Cross-country (US-ROW) correlations of GDP and hours worked are sizable (about 0.45 ). Cross-country correlations of consumption and investment (about 0.35) are somewhat lower. Importantly, the cross-country correlations of (growth rates of) GDP, consumption, investment and hours are noticeably higher than the cross-country correlation of productivity growth rates $(0.13)$. To explain the fact that endogenous variables are more strongly correlated across countries than the driving process, the model will have to generate positive international shock transmission (synchronized domestic and foreign responses to country-specific productivity shocks).

\section{Model predictions}

Table 2 reports predicted standard deviations and cross-correlations of key variables generated by different model variants. Predicted moments of GDP, consumption, investment, hours worked and the real exchange rate pertain to first differenced logged variables, while moments for 'net exports' pertain to the first differenced net exports/GDP ratio. The Table also reports the Hansen-Jagannathan (1991) bound ('HJ bound') generated by the model, i.e. the ratio of the standard deviation of the intertemporal marginal rate of substitution (IMRS) divided by the mean IMRS. That statistic allows to evaluate whether the model has the potential to generate realistic risk

\footnotetext{
${ }^{15}$ ROW aggregates for GDP, $C, I$ and $L$ (hours worked) are Törnqvist indices (GDP-weighted) of individual countries' series. The ROW NX/GDP series is a GDP-weighted average of individual countries' NX/GDP.
} 
premia on financial assets. In equilibrium, the Sharpe ratio of any traded risky asset is bounded above by the HJ bound. The historical quarterly Sharpe ratio of US equity returns was 0.22 in 1973-2013. ${ }^{16}$ Thus, a model-generated HJ bound below 0.22 indicates that the model cannot generate a realistic equity premium.

Cols. (1)-(6) of Table 2 report predicted moments generated by model variants with a flexible consumption wage rate (hereafter referred to as 'flex-wage' variants), while Cols. (7)-(12) show predicted moments generated by model variants with a predetermined consumption wage rate. For each of these model variants, I report predicted moments generated under KPR period utility (Cols. (1)-(3) and (7)-(9)) and under GHH period utility (Cols. (4)-(6) and (10)-(12)), and that for three values of the risk aversion coefficient: $\gamma=1 /$ IES (time-separable preferences); $\gamma=10$ and $\gamma=50$ (recursive preferences). Historical US moments (from Table 1) are shown in Col. (13) of Table 2.

Table 3 report dynamic effects of a one-standard deviation innovation to Home productivity, for flex-wage model variants (Panel (a)), and for model variants with a predetermined consumption wage rate (Panel (b)).

\subsection{Flex-wage model variants (Table 2, Cols. (1)-(6); Table 3, Panel (a))}

\section{Predicted moments}

Consider first the predicted moments generated by the flex-wage model variants. Those variants match well the historical volatility of US GDP; they also capture the fact that investment is more volatile than GDP, while consumption, hours and net exports are less volatile than GDP. Under all model specifications (KPR/GHH, time separable/recursive), investment and hours worked are procyclical, and the real exchange rate is countercyclical. Consumption is pro-cyclical in all model variants with GHH period utility. ${ }^{17}$ The following discussion focuses on model-predicted real exchange rate behavior and international correlations.

The flex-wage model variants with time-separable preferences, $\gamma=1 /$ IES, (Table 2, Cols. (1) and (4)) show well-known shortcomings of standard international macro models (e.g., Backus et al. (1994)); in particular, the predicted cross-country correlations of GDP,

\footnotetext{
${ }^{16}$ Based on returns data from Ken French's data base. The Sharpe ratio of an asset is the ratio of the mean of its excess return (relative to a risk-free asset) divided by its standard deviation.

${ }^{17}$ Consumption is countercyclical in model variants with KPR period utility and recursive intertemporal preferences (see discussion below).
} 
investment and hours worked are smaller than empirical cross-country correlations; this is the case under both KPR and GHH period utility. The predicted cross-country GDP correlation with $\gamma=1 /$ IES is $0.23(0.14)$ under KPR (GHH) period utility, while the empirical correlation is 0.45 . Furthermore, the predicted relative standard deviation of the real exchange rate $(0.37[0.16]$ under KPR [GHH] period utility) is much smaller than the empirical relative standard deviation (3.03). In addition, the HJ bounds generated by the model variants with time-separable preferences $(\gamma=1 / \mathrm{IES})$ are close to zero, i.e. those variants cannot generate a realistic equity premium.

The flex-wage model variants with recursive preferences, $\gamma=10$ and $\gamma=50$, (Table 2, Cols. (2),(3) and (5),(6)) generate greater real exchange rate volatility and greater HJ bounds (i.e. higher IMRS volatility) than the flex-wage model variants with timeseparable preferences $(\gamma=1 / \mathrm{IES})$. The explanation for this is that persistent countryspecific productivity shocks have a strong effect on (relative) life-time utility. With recursive preferences $(\gamma \neq 1 / \mathrm{IES})$, the IMRS is affected by unexpected changes in life-time utility. This triggers strong real exchange rate responses, as the (gross) rate of appreciation of the Home real exchange rate is equated, in equilibrium, to the ratio of the Home IMRS to the Foreign IMRS (see equations (4),(5)). The greater the risk aversion coefficient $\gamma$, the greater the volatility of the IMRS and of the real exchange rate. The KPR and GHH flex-wage model variants with $\gamma=10(\gamma=50)$ generate HJ bounds of about $0.05(0.24)$, respectively, and a relative standard deviation for the real exchange rate of about 1.2 (1.5). Hence, recursive preferences with substantial risk aversion are needed to generate a realistic $\mathrm{HJ}$ bound, and a volatile real exchange rate.

In the flex-wage setting, the effect of recursive intertemporal preferences on predicted cross-country correlations hinges on the functional form of period utility. With KPR period utility, the assumption of recursive preferences lowers the predicted crosscountry correlations of labor hours and output (compared to the correlations under timeseparable preferences), i.e. the 'international correlation puzzle' worsens. By contrast, under GHH period utility, the assumption of recursive preferences increases the predicted cross-country correlations (compared to the correlations under time-separable preferences). In the flex-wage model variant with KPR period utility and recursive preferences $(\gamma=50)$, the predicted cross-country correlations of GDP, consumption, 
investment and hours are $0.14,-0.02,0.34$ and 0.15 , respectively (Table 2, Col. (3)). The corresponding predicted correlations with GHH period utility and recursive preferences $(\gamma=50)$ are $0.35,0.65,0.64$ and 0.62 (Table 2, Col. (6)). In the flex-wage model variant with GHH period utility and recursive preferences, the predicted cross-country correlation of GDP remains thus below the empirical correlation (0.45), but the predicted cross-country correlations of consumption, investment and hours exceed the corresponding empirical correlations.

\section{Impulse responses}

The dynamic responses to a positive one-standard deviation (0.78\%) Home productivity innovation reported in Table 3 (Panel (a)) help to understand these properties of the flexwage model variants. The Home productivity shock triggers a persistent rise in Home GDP, consumption and investment; it deteriorates the Home terms of trade, and depreciates the Home real exchange rate. Home hours worked rise (the rise is more persistent under GHH period utility than under KPR period utility). Under time-separable preferences $(\gamma=1 / \mathrm{IES})$, the real exchange rate (and terms of trade) response is modest. With both KPR and GHH period utility, Foreign labor hours, GDP and investment rise slightly, consistent with the modest improvement in the Foreign terms of trade (Table 3, Panels (a1) and (a3), Cols. (2),(8) and (9)). That muted response of Foreign real activity explains the low predicted cross-country business cycle correlations generated by the flex-wage model variants with time-separable preferences (see above).

Recursive preferences $(\gamma>1 /$ IES) magnify the real exchange rate response to the Home productivity increase (see Table 3, Panels (a2) and (a4), Col. (9)). A positive Home productivity shock raises Home lifetime utility. When $\gamma>1$ IES, this lowers the Home country's IMRS (between the period preceding the shock and the date of the shock); see equation (4). (Foreign life-time utility rises less, because of consumption home bias.) Hence the Home real exchange rate depreciates much more under recursive intertemporal preferences (with high risk aversion) than under time-separable preferences (in response to the Home productivity increase). This implies that the Home terms of trade too deteriorate much more sharply, under recursive preferences. For example, in the flexwage structure with GHH period utility, the Home real exchange rate depreciates by 
$0.99 \%$ on impact, under recursive preferences $(\gamma=50)$, compared to a $0.010 \%$ depreciation under time-separable preferences (the corresponding changes of the Home terms of trade are $-1.24 \%$ and $-0.012 \%$, respectively).

Under recursive preferences, Home consumption rises markedly less than under time-separable preferences, while Foreign consumption rises more than under timeseparable preferences (in response to the Home productivity increase). ${ }^{18}$ The greater deterioration of the Home terms of trade (with recursive preferences) dampens the rise in Home investment, and it boosts the rise in Foreign investment. The weakened rise in Home absorption, under recursive preferences, implies that Home net exports rise persistently, in response to the Home productivity increase. Thus, Home net foreign assets (the present value of Home net imports) fall, on impact (by about 7\% of quarterly GDP)

Efficient risk sharing with recursive preferences implies hence that the Home household (whose relative IMRS has dropped) makes a wealth transfer to the Foreign household. That risk sharing transfer boosts demand for the Foreign traded good (and lowers demand for the Home traded good), which amplifies the depreciation of the Home real exchange rate; the wealth transfer thereby aligns the relative Home/Foreign IMRS and the real exchange rate change.

In a flex-wage setting with KPR period utility, Foreign hours worked rise less under recursive preferences ( $\gamma>1 / \mathrm{IES})$ than under time-separable preferences, and may even fall (in response to the Home productivity increase). Intuitively, the sizable wealth transfer from Home to Foreign, that occurs under recursive preferences, dampens the expansion of the Foreign labor supply and output, when the labor wealth effect is negative. This explains why, in a flex-wage setting with KPR period utility, the assumption of recursive preferences lowers the predicted cross-country correlations of labor hours and output (compared to the correlations under time-separable preferences), as discussed above. By contrast, in a flex-wage setting with GHH period utility (zero labor wealth effect), Foreign hours and GDP rise more strongly (in response to the Home productivity increase), when recursive preferences are assumed (compared to timeseparable preferences); this reflects the stronger rise in Foreign labor demand (without

\footnotetext{
${ }^{18}$ With recursive preferences and KPR period utility, Home consumption actually falls on impact. This explains why consumption is countercyclical, in that model configuration, as mentioned above.
} 
counteracting negative labor supply wealth effect), due to the stronger improvement of the Foreign terms of trade, under recursive preferences. These results highlight that recursive preferences and a muted labor wealth effect are jointly needed for generating cross-country business cycle synchronization.

\subsection{Predetermined-wage model variants (Table 2, Cols. (7)-(12); Table 3, Panel (b))}

A positive innovation to Home productivity induces, on impact, a stronger rise in Home labor hours, GDP and investment, when the consumption wage rate is set one period in advance, than when the consumption wage rate is flexible. This holds for all preference specifications considered here, and is due to the fact that hours worked are demanddetermined, in the predetermined-wage model. On impact, workers are pushed off their desired labor supply schedule. However, one period after the shock, workers are again on their desired labor supply schedule; thus, shock responses after the impact period are similar to the ones predicted by the flex-wage model. ${ }^{19}$ With a predetermined consumption wage rate, the effect of the Home productivity increase on the real exchange rate remains similar to the effect in a flex-wage setting; thus the Home real exchange rate (and terms of trade) depreciation triggered by the shock is again much stronger under recursive preferences $(\gamma>1 /$ IES) than under time-separable preferences (Table 3 , Panel (b), Col. (9)).

Importantly, the recursive-preferences model variants with a predetermined consumption wage rate predict that a Home productivity increase triggers a strong initial rise in Foreign hours worked and GDP (Table 3, Panels (b2),(b4), Cols. (2) and (8)). With high risk aversion $\gamma=50$, a one-standard deviation innovation to Home productivity raises Home and Foreign GDP by about $1.2 \%$ and $0.2 \%$, respectively, on impact, under both KPR and GHH period utility. Intuitively, the sizable Foreign terms of trade improvement under recursive preferences boosts Foreign labor demand more strongly when the consumption wage rate cannot adjust, on impact. (By contrast, with wage

\footnotetext{
${ }^{19}$ The stronger initial rise in Home GDP, under a predetermined consumption wage rate, explains why the predicted standard deviation of output (about 1.4\%) is higher than in a flex-wage structure. Also, the predicted relative standard deviation of hours worked is now larger than the empirical relative standard deviation. By contrast, the flex-wage model variants yield a relative volatility of hours worked that is below empirical relative hours volatility.
} 
flexibility, a rise in Foreign labor demand increases the Foreign consumption wage rate, which dampens the rise in hours worked.)

Under both KPR and GHH period utility, the predetermined-wage model variant with recursive preferences and high risk aversion $\gamma=50$ generate a cross-country output correlation of about 0.5 (see Table 2, Cols. (9), (12)), which is close to the empirical cross-country GDP correlation, 0.45 . That model variant also generates sizable predicted cross-country correlations of consumption, investment and hours worked (in the range 0.5-0.7).

By contrast, under time-separable preferences, the assumption of a predetermined consumption wage rate does not raise the cross-country GDP correlation (compared to the flex-wage structure), due to the muted response of the real exchange rate (and the terms of trade) to productivity shocks, in that setting (Table 3, Panels (b1) and (b3), Col. (9)).

These findings confirm that recursive preferences and a weak labor wealth effect are jointly needed for international business cycle synchronization. Consumption wage rigidity induces especially powerful cross-country shock transmission, in conjunction with recursive preferences.

\section{Conclusion}

This paper has presented a simple model of a world with two countries, two traded goods, complete financial markets, exogenous productivity shocks, and recursive intertemporal preferences. Recursive preferences magnify the terms of trade response to countryspecific productivity shocks, which strengthens positive cross-country shock transmission, if a muted response of labor hours to household wealth changes is assumed. The recursive-preferences model with a muted labor wealth effect generates crosscountry correlations of GDP, hours worked and investment growth rates that are markedly higher than the cross-country correlation of productivity growth. 


\section{References}

Adjemian, Stéphane, Houtan Bastani, Frédéric Karamé, Michel Juillard, Junior Maih, Ferhat Mihoubi, George Perendia, Johannes Pfeifer, Marco Ratto and Sébastien Villemot, 2014. Dynare: Reference Manual, Version 4.4.3, CEPREMAP, Paris.

Backus, David, Patrick Kehoe, and Finn Kydland, 1992. International Real Business Cycles. Journal of Political Economy, 100, 745-775.

Backus, David, and Gregor Smith, 1993. Consumption and Real Exchange Rates in Dynamic Economies with Non-traded Goods. Journal of International Economics 35, 297-316.

Backus, David, Patrick Kehoe, and Finn Kydland, 1994. Dynamics of the Trade Balance and the Terms of Trade: The J-Curve? American Economic Review 84, 84-103.

Backus, David, Chase Coleman, Axelle Ferriere and Spencer Lyon, 2016. Risk and Risksharing in Two-Country Models. Journal of Economic Dynamics and Control 72.

Benigno, Gianluca, Pierpaolo Benigno and Salvatore Nisticò, 2012. Risk, Monetary Policy, and the Exchange Rate. NBER Macroeconomics Annual Volume 26, 247-309.

Blanchard, Olivier and Jordi Gali, 2007. Real Wage Rigidities and the New Keynesian Model. Journal of Money, Credit and Banking 39(S1), 35-61.

Cantor, Richard and Nelson Mark, 1988. The International Transmission of Real Business Cycles. International Economic Review 29, 493-507

Caporale, Guglielmo Maria, Michael Donadelli and Alessia Varani, 2014. International Capital Markets Structure, Preferences and Puzzles: The US-China Case. CESifo Working Paper 4669.

Colacito, Riccardo and Mariano Croce, 2011. Risks for the Long Run and the Real Exchange Rate. Journal of Political Economy 119, 153-182.

Colacito, Riccardo and Mariano Croce, 2013. International Asset Pricing with Recursive Preferences. Journal of Finance 68, 2651-2686.

Colacito, Riccardo, Mariano Croce, Steven Ho and Philip Howard, 2014. BKK the EZ Way. Working Paper, University of North Carolina.

Correia, Isabel and Sergio Rebelo, 1995. Business Cycles in Small Open Economies. European Economic Review 39, 1089-1113.

Crucini, M., 1989, A two-country real business cycle model. Working Paper, University of Rochester.

Dellas, Harris, 1986. A Real Model of the World Business Cycle. Journal of International Money and Finance 5. 381-294.

Devereux, Michael B., Alan Gregory and Gregor Smith, 1992. Realistic Cross-Country Consumption Correlations in a Two-Country, Equilibrium, Business Cycle Model. Journal of International Money and Finance 11, 3-16.

Dou, Wei and Adrien Verdelhan, 2015. The Volatility of International Capital Flows and Foreign Assets. Working Paper, MIT.

Epstein, Larry and Stanley Zin, 1989. Substitution, Risk Aversion, and the Temporal Behavior of Consumption and Asset Returns: A Theoretical Framework. Econometrica 57, 937-969.

Gourio, François, Michael Siemer and Adrien Verdelhan, 2013. International Risk Cycles. Journal of International Economics 89, 471-484.

Greenwood, Jeffrey, Zvi Hercowitz and Gregory Huffman, 1988. Investment, Capacity Utilization and the Real Business Cycle 27, 402-417. 
Hansen, Lars Peter and Ravi Jagannathan, 1991. Implications of Security Market Data for Models of Dynamic Economies. Journal of Political Economy 99, 225-262.

Heathcote, Jonathan and Fabrizio Perri, 2002. Financial Globalization and Real Regionalization. Journal of Economic Theory 119, 207-243.

Jaimovich, Nir and Sergio Rebelo, 2008. News and Business Cycles in Open Economies. Journal of Money, Credit and Banking 40, 1699-1711.

King, Robert, Charles Plosser and Sergio Rebelo, 1988. Production, Growth and Business Cycles: I. The Basic Neoclassical Model. Journal of Monetary Economics 21, 195-232.

Kollmann, Robert, 1991. Essays on International Business Cycles. PhD Dissertation, Economics Department, University of Chicago.

Kollmann, Robert, 1995. Consumption, Real Exchange Rates and the Structure of International Asset Markets. Journal of International Money and Finance 14, 191-211.

Kollmann, Robert, 1996. Incomplete Asset Markets and the Cross-Country Consumption Correlation Puzzle. Journal of Economic Dynamics and Control 20, 945-962.

Kollmann, Robert, 2009. EZW in a World Economy. Working Paper, ECARES, Université Libre de Bruxelles.

Kollmann, Robert, 2010. International Real Business Cycles with Epstein-Zin-Weil Preferences. Working Paper, ECARES, Université Libre de Bruxelles.

Kollmann, Robert, 2015. Exchange Rate Dynamics with Long-Run Risk and Recursive Preferences. Open Economies Review 26, 175-196.

Kollmann, Robert, 2016. International Business Cycles and Risk Sharing with Uncertainty Shocks and Recursive Preferences. Journal of Economic Dynamics and Control 72, 115-124.

Kollmann, Robert, Beatrice Pataracchia, Rafal Raciborski, Marco Ratto, Werner Roeger and Lukas Vogel, 2016. The Post-Crisis Slump in the Euro Area and the US: Evidence from an Estimated Three-Region DSGE Model. European Economic Review 88, 21-41.

Küçük, Hande, 2011. Essays on International Portfolio Allocation and Risk Sharing. PhD Dissertation. Economics Department, London School of Economics.

Lewis, Karen and Edith Liu, 2015. Evaluating International Consumption Risk Sharing Gains: An Asset Return View. Journal of Monetary Economics 71, 84-98.

Lustig, Hanno, and Adrien Verdelhan, 2015. Does Incomplete Spanning in International Financial Markets Help to Explain Exchange Rates? Working Paper, MIT.

Mumtaz, Haroon and Konstantinos Theodoridis, 2015. Common and Country Specific Economic Uncertainty. Working Paper 752, Queen Mary College, London.

Ohanian, Lee and Andrea Raffo, 2012. Aggregate Hours Worked in OECD Countries: New Measurement and Implications for Business Cycles. Journal of Monetary Economics 59, 40-56.

Ohanian, Lee and Andrea Raffo, 2014. Updated dataset (1960-2013) on Aggregate Hours Worked in OECD Countries (posted on A. Raffo's web page).

Raffo, Andrea, 2010. Technology Shocks: Novel Implications for International Business Cycles. Federal Reserve Board, International Finance Discussion Paper 992.

Rudebusch, Glenn and Eric Swanson, 2012. The Bond Premium in a DSGE Model with Long-Run Real and Nominal Risks. American Economic Journal: Macroeconomics 4, 105-143.

Sauzet, Maxime, 2014. Great Retrenchment, Financial Contagion and International RiskSharing. Working Paper, Sciences Po, Paris. 
Swanson, Eric, 2014. A Macroeconomic Model of Equities and Real, Nominal, and Defaultable Debt. Working Paper, UC Irvine.

Tretvoll, Håkon, 2016. Real Exchange Rate Variability in a Two-Country Business Cycle Model. Working Paper, BI Norwegian Business School.

Weil, Philippe, 1989. The Equity Premium Puzzle and the Risk-Free Rate Puzzle. Journal of Monetary Economics 24, 401-421.

Weil, Philippe, 1990. Nonexpected Utility in Macroeconomics, Quarterly Journal of Economics 105, 29-42. 
Table 1. Historical statistics (1973-2013)

\begin{tabular}{|c|c|c|}
\hline & US & ROW \\
\hline \multicolumn{3}{|c|}{ Standard deviations (in \%) } \\
\hline GDP & 0.81 & 0.59 \\
\hline \multicolumn{3}{|c|}{ Standard deviations relative to GDP } \\
\hline Consumption & 0.66 & 0.74 \\
\hline Investment & 4.09 & 3.53 \\
\hline Hours worked & 0.89 & 0.71 \\
\hline Net exports/GDP & 0.40 & 0.48 \\
\hline Real exchange rate & 3.03 & n.a. \\
\hline \multicolumn{3}{|c|}{ Correlations with domestic GDP } \\
\hline Consumption & 0.63 & 0.67 \\
\hline Investment & 0.84 & 0.73 \\
\hline Hours worked & 0.71 & 0.43 \\
\hline Net exports/GDP & -0.23 & 0.04 \\
\hline Real exchange rate & -0.07 & n.a. \\
\hline \multicolumn{3}{|c|}{ Cross-country correlations } \\
\hline GDP & & 0.45 \\
\hline Consumption & & 0.35 \\
\hline Investment & & 0.34 \\
\hline Hours worked & & 0.43 \\
\hline
\end{tabular}

Note: Empirical statistics (1973q1-2013q4) are shown for quarterly macroeconomic variables in the US and in an aggregate of 13 other OECD economies ('ROW'); see text for list of countries. The statistics pertain to first differenced data. 'Consumption' is the sum of private and government consumption. 'Investment' is gross investment (private and public).

GDP, consumption, investment, hours worked and the real exchange rate are logged before first differencing. ROW aggregates of GDP, consumption, investment and hours worked are GDP-weighted Törnqvist indices of variables in individual ROW countries. ROW net exports/GDP is a GDP-weighted average of NX/GDP in individual countries. The GDP weights (used for the construction of ROW aggregates) are smoothed GDP shares in aggregate ROW GDP (see main text).

The real exchange rate is the US (trade weighted) real effective exchange rate (CPI based). A rise in RER represents an appreciation. Due to limited data availability, statistics for the real effective exchange rate are only shown for the US.

Data sources-Hours worked: US Bureau of Labor Statistics; Ohanian and Raffo (2012, 2014). All other data are from the OECD statistics database. 
Table 2. Predicted moments: model variants with flexible $\&$ predetermined consumption wage rate, KPR \& GHH period utility, different value of risk aversion coefficient $(\gamma)$

\begin{tabular}{|c|c|c|c|c|c|c|c|c|c|c|c|c|c|}
\hline & \multicolumn{6}{|c|}{ Flexible consumption wage rate } & \multicolumn{6}{|c|}{ Predetermined consumption wage rate } & \multirow{4}{*}{$\frac{\text { Data }}{(12)}$} \\
\hline & \multicolumn{3}{|c|}{ KPR utility } & \multicolumn{3}{|c|}{ GHH utility } & \multicolumn{3}{|c|}{ KPR utility } & \multicolumn{3}{|c|}{ GHH utility } & \\
\hline & $\gamma=1 / \mathrm{IES}$ & $\gamma=10$ & $\gamma=50$ & $\gamma=1 / \mathrm{IES}$ & $\gamma=10$ & $y=50$ & $\gamma=1 / \mathrm{IES}$ & $\gamma=10$ & $\gamma=50$ & $\gamma=1 / \mathrm{IE}$ & $\gamma=10$ & $\gamma=50$ & \\
\hline & (l) & (2) & (3) & (4) & (5) & (6) & (7) & (8) & (9) & (10) & (11) & (12) & \\
\hline \multicolumn{14}{|c|}{ Standard deviations (in \%) } \\
\hline Y & 0.82 & 0.84 & 0.85 & 0.90 & 0.85 & 0.84 & 1.52 & 1.38 & 1.36 & 1.54 & 1.39 & 1.36 & 0.81 \\
\hline \multicolumn{14}{|c|}{ Standard deviations relative to GDP } \\
\hline $\mathrm{C}$ & 0.22 & 0.22 & 0.25 & 0.48 & 0.36 & 0.39 & 0.49 & 0.48 & 0.48 & 0.81 & 0.72 & 0.72 & 0.66 \\
\hline I & 3.95 & 3.62 & 3.49 & 3.58 & 3.37 & 3.37 & 5.58 & 5.07 & 4.92 & 2.27 & 2.14 & 2.13 & 4.09 \\
\hline $\mathrm{L}$ & 0.61 & 0.63 & 0.63 & 0.67 & 0.62 & 0.61 & 1.12 & 1.07 & 1.07 & 1.08 & 1.04 & 1.03 & 0.89 \\
\hline NX & 0.10 & 0.05 & 0.08 & 0.16 & 0.09 & 0.15 & 0.13 & 0.04 & 0.04 & 0.17 & 0.08 & 0.10 & 0.40 \\
\hline RER & 0.37 & 1.32 & 1.51 & 0.16 & 1.21 & 1.53 & 0.22 & 0.82 & 0.95 & 0.09 & 0.75 & 0.95 & 3.03 \\
\hline \multicolumn{14}{|c|}{ Correlations with domestic GDP } \\
\hline C & 0.42 & -0.18 & -0.28 & 0.70 & 0.41 & 0.26 & -0.81 & -0.82 & -0.83 & 0.95 & 0.92 & 0.89 & 0.63 \\
\hline & 0.98 & 0.98 & 0.98 & 0.96 & 0.94 & 0.94 & 0.98 & 0.98 & 0.98 & 0.94 & 0.94 & 0.93 & 0.84 \\
\hline $\mathrm{L}$ & 0.97 & 0.98 & 0.98 & 0.99 & 0.99 & 0.98 & 0.97 & 0.97 & 0.97 & 0.98 & 0.98 & 0.97 & 0.71 \\
\hline NX & -0.62 & 0.57 & 0.61 & -0.64 & -0.04 & 0.11 & -0.62 & -0.09 & 0.27 & -0.65 & -0.49 & -0.29 & -0.23 \\
\hline RER & -0.60 & -0.65 & -0.66 & -0.13 & -0.55 & -0.53 & -0.55 & -0.50 & -0.48 & -0.06 & -0.48 & -0.45 & -0.07 \\
\hline \multicolumn{14}{|c|}{ Cross-country correlations } \\
\hline Y & 0.23 & 0.15 & 0.14 & 0.14 & 0.31 & 0.35 & 0.21 & 0.47 & 0.52 & 0.14 & 0.40 & 0.47 & 0.45 \\
\hline C & 0.13 & 0.13 & -0.02 & -0.30 & 0.70 & 0.65 & 0.24 & 0.63 & 0.69 & -0.09 & 0.55 & 0.69 & 0.35 \\
\hline 1 & 0.19 & 0.31 & 0.34 & 0.21 & 0.56 & 0.64 & 0.11 & 0.60 & 0.70 & 0.04 & 0.44 & 0.54 & 0.34 \\
\hline $\mathrm{L}$ & 0.38 & 0.19 & 0.15 & 0.15 & 0.53 & 0.62 & 0.23 & 0.65 & 0.73 & 0.14 & 0.52 & 0.61 & 0.43 \\
\hline
\end{tabular}

\section{Hansen-Jagannathan bound}

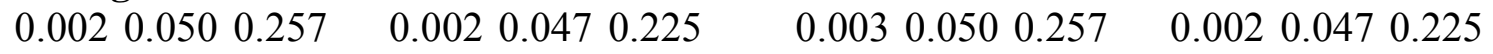

\footnotetext{
Note: This Table reports predicted moments (of variables listed in the left-most Column) generated by model variants with a flexible consumption wage rate (Cols. (1)-(6)) and by model variants with a predetermined consumption wage rate (Cols. (7)-(12)). Cols. (1)-(3) and (7)-(9) assume a period utility function of the King, Plosser and Rebelo (1988) [KPR] type, while Cols. (4)-(6) and (10)-(12) assume a period utility function of the Greenwood, Hercowitz and Huffman (1988) [GHH] type. Cols. (1),(4),(7),(10) assume risk aversion $\gamma=1 /$ IES $=0.66$ (time-separable preferences); Cols. (2),(5),(8),(11) assume risk aversion $\gamma=10$ (recursive preferences); Cols. (3),(6),(9),(12) assume risk aversion $\gamma=50$ (recursive preferences). (IES: intertemporal elasticity of substitution.) Col. (13) shows empirical statistics for the US (from Table 1).

Moments reported for GDP (Y), consumption (C), investment (I), hours worked (L) and the real exchange rate (RER) pertain to log growth rates of these variables. Statistics for net exports (NX) pertain to the first difference of the net exports/GDP ratio. A rise in RER represents an appreciation.

The Hansen-Jagannathan is the ratio of the unconditional standard deviation of the intertemporal marginal rate of substitution (IMRS), divided by the unconditional mean of the IMRS.

The Table reports simulated moments. For each model variant, a simulation run of 55000 periods was generated (initialized at the deterministic steady state); the first 5000 periods were discarded (to reduce influence of initial conditions); reported moments were computed using the remaining 50000 periods. The same simulation path for exogenous productivity is used for all model variants. Averaging moments across repeated shorter simulation runs (e.g. of length 164 periods, the number of periods in the historical sample) produces results close to the figures reported in the Table.
} 
Table 3. Dynamic responses to a Home country productivity innovation (1 standard dev.)

\begin{tabular}{cccccccccccc} 
Horizon & $Y_{H}$ & $Y_{F}$ & $C_{H}$ & $C_{F}$ & $I_{H}$ & $I_{F}$ & $L_{H}$ & $L_{F}$ & $R E R_{H}$ & $N X_{H}$ & $N F A_{H}$ \\
\hline & $(1)$ & $(2)$ & $(3)$ & $(4)$ & $(5)$ & $(6)$ & (7) & (8) & (9) & (10) & (11)
\end{tabular}

(a) Flexible consumption wage rate (a1) KPR period utility; risk aversion $\gamma=1 /$ IES

$\begin{array}{llllllllllll}0 & 0.81 & 0.04 & 0.08 & -0.03 & 3.09 & 0.11 & 0.46 & 0.06 & -0.22 & -0.06 & 1.98 \\ 4 & 0.78 & 0.05 & 0.33 & -0.01 & 2.15 & 0.18 & 0.28 & 0.06 & -0.29 & -0.05 & 1.86 \\ 50 & 0.70 & 0.08 & 0.68 & 0.09 & 0.64 & 0.14 & -0.02 & 0.02 & -0.37 & -0.02 & 1.47\end{array}$

(a2) KPR period utility; risk aversion $\gamma=50$

$\begin{array}{lrlrlrllllll}0 & 0.84 & 0.00 & -0.07 & 0.12 & 2.46 & 0.33 & 0.51 & 0.00 & -1.00 & 0.05 & -7.91 \\ 4 & 0.81 & 0.01 & 0.16 & 0.16 & 1.82 & 0.33 & 0.34 & -0.01 & -1.06 & 0.07 & -8.02 \\ 50 & 0.74 & 0.03 & 0.50 & 0.28 & 0.59 & 0.18 & 0.07 & -0.07 & -1.09 & 0.08 & -8.03\end{array}$

(a3) GHH period utility; risk aversion $\gamma=1 /$ IES

\begin{tabular}{|c|c|c|c|c|c|c|c|c|c|c|c|}
\hline 0 & 0.89 & 0.00 & 0.31 & -0.19 & 3.06 & 0.13 & 0.60 & 0.00 & -0.01 & -0.11 & 8.49 \\
\hline 4 & 1.06 & 0.02 & 0.58 & -0.16 & 2.86 & 0.20 & 0.69 & 0.03 & -0.12 & -0.11 & 8.38 \\
\hline 50 & 1.75 & 0.27 & 1.75 & 0.16 & 1.88 & 0.47 & 1.10 & 0.22 & -0.54 & -0.10 & 7.09 \\
\hline \multicolumn{12}{|c|}{ (a4) GHH period utility; risk aversion $\gamma=50$} \\
\hline 0 & 0.80 & 0.09 & 0.03 & 0.09 & 2.41 & 0.88 & 0.45 & 0.15 & -0.99 & 0.07 & -6.47 \\
\hline 4 & 0.93 & 0.16 & 0.24 & 0.18 & 2.26 & 0.89 & 0.53 & 0.19 & -1.04 & 0.07 & -6.51 \\
\hline 50 & 1.48 & 0.55 & 1.18 & 0.73 & 1.50 & 0.88 & 0.86 & 0.47 & -1.20 & 0.07 & -6.9 \\
\hline
\end{tabular}

(b) Predetermined consumption wage rate

(b1) KPR period utility; risk aversion $\gamma=1 /$ IES

$\begin{array}{lrlrrrrrrrrr}0 & 1.39 & 0.06 & -0.38 & -0.04 & 6.90 & -0.02 & 1.36 & 0.09 & -0.26 & -0.13 & 1.93 \\ 4 & 0.77 & 0.05 & 0.39 & -0.01 & 1.90 & 0.21 & 0.23 & 0.06 & -0.31 & -0.04 & 1.84 \\ 50 & 0.70 & 0.08 & 0.68 & 0.09 & 0.64 & 0.14 & -0.02 & 0.02 & -0.37 & -0.02 & 1.47\end{array}$

(b2) KPR period utility; risk aversion $\gamma=\mathbf{5 0}$

\begin{tabular}{|c|c|c|c|c|c|c|c|c|c|}
\hline 1.21 & 0.24 & -0.36 & -0.06 & 5.02 & 1.73 & 1.09 & 0.36 & -1.01 & 0.04 \\
\hline 0.81 & 0.01 & 0.20 & 0.18 & 1.68 & 0.26 & 0.31 & -0.03 & -1.07 & 0.07 \\
\hline 0.74 & 0.03 & 0.50 & 0.28 & 0.59 & 0.18 & 0.07 & -0.07 & -1.09 & 0.08 \\
\hline
\end{tabular}

(b3) GHH period utility; risk aversion $\gamma=1 /$ IES

\begin{tabular}{|c|c|c|c|c|c|c|c|c|c|c|c|}
\hline 0 & 1.45 & 0.00 & 1.05 & -0.19 & 3.31 & -0.13 & 1.44 & 0.01 & -0.02 & -0.18 & 8.44 \\
\hline 4 & 1.06 & 0.02 & 0.58 & -0.17 & 2.86 & 0.21 & 0.69 & 0.03 & -0.12 & -0.11 & 8.38 \\
\hline 50 & 1.75 & 0.27 & 1.75 & 0.16 & 1.88 & 0.47 & 1.10 & 0.22 & -0.54 & -0.10 & 7.09 \\
\hline \multicolumn{12}{|c|}{ (b4) GHH period utility; risk aversion $\gamma=50$} \\
\hline 0 & 1.22 & 0.23 & 0.59 & 0.27 & 2.55 & 0.75 & 1.09 & 0.35 & -0.99 & 0.03 & -6.46 \\
\hline 4 & 0.93 & 0.15 & 0.24 & 0.17 & 2.26 & 0.89 & 0.53 & 0.19 & -1.04 & 0.07 & -6.53 \\
\hline 50 & 1.48 & 0.55 & 1.18 & 0.73 & 1.50 & 0.88 & 0.86 & 0.47 & -1.20 & 0.07 & -6.95 \\
\hline
\end{tabular}

Note: The Table shows effects of an exogenous one-time innovation ( 1 std, $0.78 \%)$ to Home productivity on selected variables after 0, 4 and 50 quarters (see left-most Column labeled 'Horizon'). Cols. (1)-(8) show responses of Home and Foreign GDP $\left(Y_{H}, Y_{F}\right)$, consumption $(C)$, investment $(I)$, hours worked $(L)$. Cols. (9)-(11) show responses of the Home real exchange rate $(R E R)$, net exports $(N X)$ and net foreign assets $(N F A)$. A rise in $R E R$ is an appreciation. Net exports and net foreign assets are normalized by Home GDP. Responses of GDP, consumption, investment and hours are expressed as \% deviations from unshocked paths. Responses of net exports and net foreign assets are expressed as percentage point differences from unshocked paths. All predetermined state variables are set at their unconditional mean, in the period of the shock (period 0 ). $\gamma$ : risk aversion; IES: intertemporal elasticity of substitution. Dynamic responses are shown for 8 model variants:

Panel (a1): flex-wage, KPR period utility, $\gamma=1 / \mathrm{IES}=0.66$ (time-separable pref.), (corresponds to Col. (1) in Table 1); Panel (a2): flex-wage, KPR period utility, $\gamma=50$ (recursive preferences), (corresponds to Col. (3) in Table 1); Panel (a3): flex-wage, GHH period utility, $\gamma=1 / \mathrm{IES}=0.66$ (time-separable pref.), (corresponds to Col. (4) in Table 1); Panel (a4): flex-wage, GHH period utility, $\gamma=50$ (recursive preferences), (corresponds to Col. (6) in Table 1); 
Panel (b1): predetermined wage, KPR period utility, $\gamma=1 / \mathrm{IES}=0.66$ (time-separable), (corresponds to Col. (7) in Table 1); Panel (b2): predetermined wage, KPR period utility, $\gamma=50$ (recursive preferences), (corresponds to Col. (9) in Table 1); Panel (b3): predetermined wage, GHH period utility, $\gamma=1 / \mathrm{IES}=0.66$ (time-separable), (corresponds to Col. (10) in Table 1); Panel (b4): predetermined wage, GHH period utility, $\gamma=50$ (recursive preferences), (corresponds to Col. (12) in Table 1). 